\title{
Effect of Dietary Grape Pomace on Fattening Rabbit Performance, Fatty Acid Composition, and Shelf Life of Meat
}

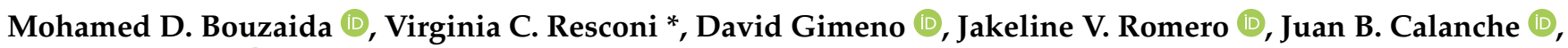

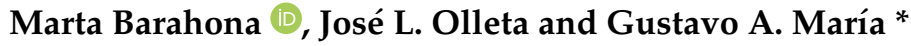

\author{
Departamento de Producción Animal y Ciencia de los Alimentos, Facultad de Veterinaria, \\ Instituto Agroalimentario de Aragón IA2, Universidad de Zaragoza-CITA, 50013 Zaragoza, Spain; \\ bouzaidadhia@gmail.com (M.D.B.); dgimeno@unizar.es (D.G.); jakromero@unizar.es (J.V.R.); \\ calanche@unizar.es (J.B.C.); martabm@unizar.es (M.B.); olleta@unizar.es (J.L.O.) \\ * Correspondence: resconi@unizar.es (V.C.R.); levrino@unizar.es (G.A.M.); Tel.: +34-976-762-490 (G.A.M.)
}

check for updates

Citation: Bouzaida, M.D.; Resconi, V.C.; Gimeno, D.; Romero, J.V.; Calanche, J.B.; Barahona, M.; Olleta, J.L.; María, G.A. Effect of Dietary Grape Pomace on Fattening Rabbit Performance, Fatty Acid Composition, and Shelf Life of Meat. Antioxidants 2021, 10, 795. https:// doi.org/10.3390/antiox10050795

Academic Editor: Jose M. Lorenzo

Received: 20 April 2021

Accepted: 13 May 2021

Published: 17 May 2021

Publisher's Note: MDPI stays neutral with regard to jurisdictional claims in published maps and institutional affiliations.

Copyright: (c) 2021 by the authors. Licensee MDPI, Basel, Switzerland. This article is an open access article distributed under the terms and conditions of the Creative Commons Attribution (CC BY) license (https:/ / creativecommons.org/licenses/by/ $4.0 /)$.
Abstract: The use of agroindustry by-products in animal diets allows the use of residues that are not fit for human consumption. In this study, it was investigated whether fattening commercial rabbits during 30 days with a non-medicated feed, with $20 \%$ addition of grape pomace (GPD), affected production traits and the fatty acid composition, antioxidants properties, and the shelf life of the meat compared to a conventional strategy (CON). Furthermore, it was tested, by chromatographic analysis, whether this alternative diet allowed the transfer of phenolic compounds to the meat. Thirty-six weaned rabbits were allotted to the two treatments. In each treatment, 18 rabbits were fattened in three indoor cages, each housing three males and three female rabbits. No significant differences were found in live weights $(p>0.05)$, but the feed conversion rate and carcass weight and yield were found to be impaired in the GPD group $(p \leq 0.05)$. The GPD group had a higher intramuscular fat percentage (2.01 vs. 1.54$)$, improved polyunsaturated/saturated fatty acids ratio ( 0.75 vs. 0.66$)$, and better atherogenicity ( 0.71 vs. 0.83 ) and thrombogenicity ( 1.14 vs. 1.24$)$ indexes, while the $n-6 / n-3$ ratio was higher (25.4 vs. 20.3). Total volatile basic nitrogen in meat was lower in the GPD group $(p=0.01)$, suggesting a delayed spoilage. However, no improvements in total phenolic content, antioxidant capacity, reducing power, and lipid oxidation $(p>0.05)$ were found in the meat. Even though the GPD pellets offered to the animals had several grape-derived phenolic compounds, and higher antioxidant properties compared to the CON diet, none of the phenolic compounds detected in feeds were detected in the meat samples.

Keywords: animal feeding; grape by-product; meat quality; lipid oxidation; antioxidant properties

\section{Introduction}

Rabbit meat is traditionally part of a healthy Mediterranean diet and its nutritional characteristics, such as a low fat and cholesterol content and a favourable fatty acid profile, etc., [1], are widely recognised. The high percentage of polyunsaturated fatty acids (PUFA), including long chain $n-3$ fatty acids, means that this meat is valued in terms of human health, but at the same time this results in a greater proneness to lipid oxidation, reducing its shelf life $[2,3]$. Previous studies have shown that animal feeds can affect fatty acid composition, shelf life, and the amount of bioactive compounds in meat, and that by including certain ingredients, the potential of rabbit meat as a "functional food" can be capitalised [1]. In this respect, incorporating in animal diets by-products of industrial fruit and vegetable processes [4-6] is a well-accepted strategy due to its perceived naturalness and to the environmental benefits it affords by reducing waste.

During industrial winemaking processes large amounts of pomace are produced (mainly grape skins, pulp, seeds, and any unremoved stems), which represent almost $25 \%$ of the contents of grapes used for wine production [7]. This by-product has phenolic compounds with antimicrobial and antioxidant properties that can be used in animal feed, 
with promising results in live animals (health, productivity) and in the shelf life of their meat [8]. Additionally, grape pomace provides other secondary plant metabolites, such as tannins and lignin, and linoleic fatty acid, which could affect feed digestibility or change the fatty acid profile of the meat. In a previous study, grape pomace showed a slight reduction in protein and energy digestibility, as well as a lower feed efficiency, but it was concluded that this by-product could partially replace alfalfa hay in growing rabbits' diets (from 100 to $300 \mathrm{~g} / \mathrm{kg}$ total weight), depending on the availability and economic value of these two ingredients [4]. In rabbit bucks, including up to $20 \%$ of grape pomace in their diet improved semen quantity and quality, and also increased their antioxidant capacity without affecting body weight gain [9]. However, to the best of our knowledge, the effect of grape pomace in fattening rabbits' diets on the quality of their meat has not been assessed hitherto. Based on the aforementioned previous studies, we expect that the inclusion of $20 \%$ of grape pomace in diets will not impair animals' performance, but it could improve the shelf life of meat if the phenolic compounds from the by-product are transferred to the meat. Interesting findings have been observed in other species that could be applicable to rabbits, such as the inhibition of pathogenic bacteria in the gut in piglets [10], methane reduction in dairy cows [11], and an increase of polyunsaturated fatty acids and reduction in oxidation in the meat of chickens [12,13], pigs [14], and lambs [15].

Furthermore, in line with the European Union tendency, a specific Spanish national strategy has been developed to minimise the use of medical products in animal production. In this respect, the use of by-products rich in polyphenols can help produce food without using medicated feeds in rabbit diets, thus improving the image of the sector vis-a-vis consumers by presenting a more sustainable product.

The objective of this study was, therefore, to investigate the effect of including $20 \%$ of grape pomace by-product in non-medicated fattening rabbit diets on animal performance, and on the fatty acid composition, the phenolic profile, and shelf life of their meat, in comparison to a medicated commercial diet.

\section{Materials and Methods}

\subsection{Animals and Experimental Design}

The study that was performed at the Animal Experimentation Service of the University of Zaragoza, Spain (latitude $41^{\circ} 41^{\prime} \mathrm{N}$ ). The care and use of animals were performed in accordance with the Spanish Policy for Animal Protection RD53/2013, which meets the European Union Directive 2010/63 on the protection of animals used for experimental and other scientific purposes. Thirty-six New Zealand white rabbits were weaned at 35 days of age and allotted to two treatments, with the animals in each group balanced according to initial live weight. Each treatment consisted of three cages housing six rabbits each, balanced by sex (three females and three males), making a total of 18 animals per treatment. Treatments consisted of two ad libitum diets during 30 days:

- CON: A medicated diet (replaced by a withdrawal feed 1 week before slaughter).

- GPD: A non-medicated control diet supplemented with $20 \%$ grape pomace.

The commercial pellets contained alfalfa flour, vetch, fescue, ray-grass, barley, sunflower seed meal, corn gluten feed, soybean hulls, palm kernel pressure cake, sugar cane molasses, wheat bran, calcium carbonate, palm vegetable oil, sodium chloride, vitamins, and minerals. The CON diet had robenidine hydrochloride as the coccidiostat, unlike the withdrawal feed which was a non-medicated control diet without coccidiostat. Grape pomace from Granache grapes was supplied by a family winery from Cariñena (Aragón, Spain). The GPD was the result of mixing eight parts of 'withdrawal feed' and two parts of the grape pomace by-product. The withdrawal pellets and the by-product ground and new pellets were produced at the Animal Experimentation Service of the University of Zaragoza. Diet samples were taken during the experiment to analyse the chemical composition, total phenolic content, and antioxidant capacity (Table 1). The housing conditions established were an ambient temperature of $20^{\circ} \mathrm{C}, 16 \mathrm{~L}: 8 \mathrm{D}$ lighting schedule, and free access to drinking water. Animals were fattened in traditional, flat-deck type cages $(73 \mathrm{~cm}$ long $\times 47 \mathrm{~cm}$ 
wide $\times 30 \mathrm{~cm}$ high; $572 \mathrm{~cm}^{2} /$ head). Feed consumption and rabbit weight were recorded weekly and at the end of the fattening period, as group data of the six animals per cage. The feed conversion ratio was calculated by dividing the feed consumed $(\mathrm{kg})$ per $\mathrm{kg}$ of live weight gained.

Table 1. Chemical composition, fatty acid composition, total phenolic content, antioxidant capacity (DPPH), and reducing power (FRAP) of the two experimental diets and the wine industry grape pomace by-product.

\begin{tabular}{|c|c|c|c|}
\hline & Control Diet & Grape Pomace Diet & Grape Pomace by Product \\
\hline \multicolumn{4}{|l|}{ Chemical composition (\%) } \\
\hline Dry matter & 91.54 & 91.02 & 88.52 \\
\hline Ether extract & 4.61 & 4.97 & 7.01 \\
\hline Crude protein & 14.08 & 14.16 & 11.66 \\
\hline Neutral detergent fibre & 53.46 & 47.7 & 63.44 \\
\hline Acid detergent fibre & 33.60 & 35.04 & 57.93 \\
\hline Acid detergent lignin & 7.84 & 12.66 & 41.93 \\
\hline \multicolumn{4}{|l|}{ Fatty acid composition ( $\%$ of total fatty acids) } \\
\hline C12:0 & 12.33 & 5.90 & 0.27 \\
\hline C14:0 & 4.60 & 2.51 & 0.51 \\
\hline C16:0 & 18.65 & 18.83 & 16.95 \\
\hline C18:0 & 2.47 & 2.95 & 5.19 \\
\hline $\mathrm{C} 16: 1 n-7$ & 0.24 & 0.33 & 1.39 \\
\hline $\mathrm{C} 18: 1 n-7 \mathrm{c}$ & 0.71 & 0.85 & 1.05 \\
\hline $\mathrm{C} 18: 1 n-9 \mathrm{c}$ & 23.98 & 31.36 & 19.26 \\
\hline $\mathrm{C} 18: 2 n-6 c$ & 31.40 & 33.54 & 49.40 \\
\hline $\mathrm{C} 18: 3 n-3$ & 3.43 & 2.01 & 2.99 \\
\hline $\mathrm{C} 22: 6 n-3$ & 0.28 & 0.21 & 0.25 \\
\hline Saturated fatty acids & 39.57 & 31.25 & 25.66 \\
\hline Monounsaturated fatty acids & 25.33 & 32.99 & 21.69 \\
\hline Polyunsaturated fatty acids & 35.11 & 35.76 & 52.64 \\
\hline n-3 Polyunsaturated fatty acids & 3.71 & 2.22 & 3.24 \\
\hline n-6 Polyunsaturated fatty acids & 31.40 & 33.54 & 49.40 \\
\hline Total phenolic content (mg GAE/100 g d.w) & 224 & 491 & 1737 \\
\hline DPPH ( $\mu$ mol Trolox equivalents $/ 100 \mathrm{~g} \mathrm{d.w})$ & 3253 & 13,032 & 58,764 \\
\hline FRAP ( $\mu$ mol Trolox equivalents /100 g d.w) & 1843 & 3657 & 14,737 \\
\hline
\end{tabular}

GAE: Gallic acid equivalent; DPPH: Free radical 2.2-diphenyl-1-picrylhydrazyl; FRAP: Ferric reducing antioxidant power; d.w: Dry weight.

\subsection{Slaughtering and Meat Sampling}

At 65 days of age, 18 rabbits per group were stunned and slaughtered without fasting, at a commercial slaughterhouse located at $28 \mathrm{~km}$. After slaughter, carcasses (excluding all viscera and the distal parts of the tail and fore and hind legs, but including the head) were immediately transported to the Animal Production Unit Laboratory of the University of Zaragoza, where carcass weights were recorded. Carcass yield was obtained for the group of rabbits in each cage, calculated as the ratio between carcass weight and live weight at slaughter. Carcasses were refrigerated at $4{ }^{\circ} \mathrm{C}$ for $24 \mathrm{~h}$ and left hind leg samples were obtained, vacuum-packed, and stored at $-20{ }^{\circ} \mathrm{C}$ until analysis. Before analysing, samples were thawed at $4{ }^{\circ} \mathrm{C}$ for $24 \mathrm{~h}$, the meat was removed from the bone and minced to assess $\mathrm{pH}$, thiobarbituric acid reactive substances (TBARs), and total volatile basic nitrogen (TVB-N) at 0,4 , and 6 days of storage at $4{ }^{\circ} \mathrm{C}$, in overwrap. At day 0 , samples of hind leg were freeze-dried to analyse the total phenolic content, antioxidant capacity, reducing power, and phenolic compounds. The fat percentage and fatty acid composition of the meat was analysed in a cranial section of the right Longissimus dorsi muscles, which were minced and freeze-dried.

\subsection{Chemical Composition of the Diets, Grape Pomace, and Fat Percentage in Meat}

Analyses of diet composition, grape pomace, and fat percentage of the meat were conducted at the Agrifood Research and Technology Centre of Aragón (CITA, Zaragoza, 
Spain) at the Physical-Chemical and Instrumental Analysis Laboratory. Feedstuff samples were oven-dried to determine the dry matter content. Crude protein and ether extract were determined according to the procedures of the Association of Official Analytical Chemists (AOAC) [16]. Neutral detergent fibre, acid detergent fibre, and acid detergent lignin analyses were carried out using the sequential procedure of Van Soest et al. [17], with the Ankom fibre analyser (Model 200/220, Ankom Technology, Gomensoro, Madrid, Spain). The fat percentage in freeze-dried, minced Longissimus dorsi muscle was also analysed using the aforementioned methodology and was expressed as a percentage of fresh meat.

\subsection{Fatty Acid Composition of Diets and Rabbit Meat}

Fatty acid profiling of freeze-dried diets and Longissimus dorsi muscle samples were conducted according to the adapted methodology of Lee et al. [18] at the Institute of Food Science, Technology and Nutrition (ICTAN) in Madrid. Samples of $0.1 \mathrm{~g}$ were weighed and placed in an ultrasound cleaned (USC) culture tube. Two $\mathrm{mL}$ of $0.5 \mathrm{M}$ sodium methoxide in methanol and $1 \mathrm{~mL}$ hexane containing $1 \mathrm{mg} / \mathrm{mL} \mathrm{C13:0,} \mathrm{as} \mathrm{an} \mathrm{internal} \mathrm{standard,} \mathrm{were}$ added and then heated for $15 \mathrm{~min}$ at $50^{\circ} \mathrm{C}$. Acetyl chloride in methanol $(1: 10 ; v / v ; 2 \mathrm{~mL})$ was added before mixing thoroughly and heating for $1 \mathrm{~h}$ at $60^{\circ} \mathrm{C}$. Three $\mathrm{mL}$ of hexane, $1 \mathrm{~mL}$ of deionised water, and $0.2 \mathrm{~g}$ of anhydrous sodium sulphate were added, mixed, and centrifuged at $4{ }^{\circ} \mathrm{C}$ for $5 \mathrm{~min}$ at $1500 \mathrm{rpm}$. The organic solvent top layer was pipetted into a vial to be used for gas chromatography (GC) analysis. Fatty acid methyl esters (FAME) were assayed by gas chromatography with a flame ionization detector (Agilent 7820A), using a column $(60 \mathrm{~m} \times 0.25 \mathrm{~mm} \times 0.25 \mu \mathrm{m}$, Agilent HP-23) with split injection, $1 \mu \mathrm{L}$ (40:1), and helium at a constant flow of $1 \mathrm{~mL} / \mathrm{min}$, as the carrier gas. The detector temperature was set at $260^{\circ} \mathrm{C}$ and the injector oven temperature at $250{ }^{\circ} \mathrm{C}$. The initial temperature of the oven was $100^{\circ} \mathrm{C}$ (held for $2 \mathrm{~min}$ ) and then increased by $8{ }^{\circ} \mathrm{C} / \mathrm{min}$ to $145^{\circ} \mathrm{C}$. This temperature was held for $20 \mathrm{~min}$ and then increased by $5^{\circ} \mathrm{C} / \mathrm{min}$ to $195^{\circ} \mathrm{C}$ and held for $5 \mathrm{~min}$. Afterwards, the temperature was increased by $5^{\circ} \mathrm{C} / \mathrm{min}$ to $215^{\circ} \mathrm{C}$ and held for $5 \mathrm{~min}$, and again increased by $5{ }^{\circ} \mathrm{C} / \mathrm{min}$ to $230{ }^{\circ} \mathrm{C}$ and held for $5 \mathrm{~min}$. The total analysis time was $59.6 \mathrm{~min}$. Identification of fatty acids and their response factors was aided by the use of a reference standard (FAME 37 Supelco Ref CRM47885 + PUFA No. 2 Animal Source Ref 47015-U Sigma + PUFA No. 3 Menhaden oil Ref 47085-U) and quantified using the internal standard (C13:0).

Atherogenicity $(\mathrm{AI})$ and thrombogenicity $(\mathrm{TI})$ indices were calculated [19]: $\mathrm{AI}=(\mathrm{C} 12: 0$ $+4 \times \mathrm{C} 14: 0+\mathrm{C} 16: 0) /((\mathrm{MUFA}+n-6)+n-3)) ; \mathrm{TI}=(\mathrm{C} 14: 0+\mathrm{C} 16: 0+\mathrm{C} 18: 0) /((0.5 \times \mathrm{MUFA}+$ $0.5 \times n-6+3 \times n-3)+(n-3 / n-6))$, together with the peroxidability index (PI), according to Arakawa and Sagai [20]: PI $=(\%$ monoenoic $\times 0.025)+(\%$ dienoic $\times 1)+(\%$ trienoic $\times 2)+$ $(\%$ tetraenoic $\times 4)+(\%$ pentaenoic $\times 6)+(\%$ hexaenoic $\times 8)$.

\subsection{HPLC Analysis of Polyphenols}

The analysis was carried out on freeze-dried diets and twelve meat samples (hind legs, 6 per group), with a Waters H-Class high-performance liquid chromatography (HPLC) system coupled to a quadrupole time-of-flight mass spectrometry (QTOF) equipped with an electrospray ionization (ESI) source (microTOF-Q, Bruker Daltonik), according to the modified method of Mena et al. [21]. The column used was an analytical HPLC column (ZORBAX Eclipse Plus C18, $50 \mathrm{~mm} \times 2.1 \mathrm{~mm}$ i.d., $1.8 \mu \mathrm{m}$ spherical particle size, Agilent). Autosampler and column temperatures were 10 and $30^{\circ} \mathrm{C}$, respectively. The injection volume was $5 \mu \mathrm{L}$ and the flow rate was $0.4 \mathrm{~mL} / \mathrm{min}$. The mobile phase was built using two solvents: $0.1 \%$ formic acid in water (A), and $0.1 \%$ formic acid in acetonitrile (B). Initial conditions were $5 \%$ B for $1 \mathrm{~min}$, then a 11-min linear gradient to $30 \%$ B followed by 1-min linear gradient to $80 \% \mathrm{~B}$ and maintaining this composition for $4 \mathrm{~min}$. In order to regenerate the column a $5 \mathrm{~min}$ pre-run with $5 \% \mathrm{~B}$ was achieved before the next injection. Electrospray ionization collision-induced dissociation mass spectrometry ESI-CID-MS (QTOF) analysis was carried out in positive and negative ion mode, with capillary and endplate offset voltages of 4500 and $-500 \mathrm{~V}$ in positive mode, and 4000 and $-500 \mathrm{~V}$ in negative mode, 
using nitrogen as the collision gas. For MS/MS measurements, collision cell energies of $25 \mathrm{eV}$ were used for positive and negative mode, with an isolation width for the precursor ion of $4 \mathrm{~m} / \mathrm{z}$ units. To allow coupling with the HPLC system, the nebulizer gas $\left(\mathrm{N}_{2}\right)$ pressure and the drying gas $\left(\mathrm{N}_{2}\right)$ flow rate were 1.6 bar and $8.0 \mathrm{~L} \mathrm{~min}^{-1}$, respectively. The mass axis was calibrated externally and internally using Na-formate adducts. Bruker Daltonik o-TOF Control v.3.4, HyStar v.3.2 and Data Analysis v.4.2 software packages were used to control the MS (QTOF) apparatus, for the interface of the HPLC with the MS system and to process data, respectively. The two experimental diets, the wine industry grape pomace by-product and the meat sample extracts were ionized using the negative mode to detect phenolic acids, favan-3-ols, flavonols, and stilbenes, and the positive mode to detect anthocyanins. The resulting pseudomolecular ions $(\mathrm{M}-\mathrm{H})^{-}$or $(\mathrm{M}+\mathrm{H})^{+}$ after fragmentation by collision-induced disassociation (CID) were separated by mass to charge ratio $(m / z)$. Then, when enough collision energy was supplied, the precursor ions with a particular $\mathrm{m} / \mathrm{z}$ were fragmented again and separated in a second stage of mass spectrometry (MS/MS). Phenolic compounds were tentatively identified based on the calculated mass of pseudomolecular ions, $\mathrm{m} / \mathrm{z}$ of fragmented product ions, and retention times previously reported in the specific literature [22-31].

\subsection{Total Phenolic Content, Antioxidant Capacity, and Reducing Power}

The phenolic extract preparation was conducted in two steps. Samples of hexanedefatted and freeze-dried meat and animal diets $(1.5 \mathrm{~g})$ were homogenized in $10 \mathrm{~mL}$ of ethanol:water (80:20) using an Ultra-Turrax T25 (Janke \& Kunkel, Staufen, Germany) for $60 \mathrm{~s}$. The homogenate was then centrifuged at $4{ }^{\circ} \mathrm{C}$ for $15 \mathrm{~min}$ at $4000 \mathrm{rpm}$ and the supernatant was collected. The extracted pellets were homogenised in $10 \mathrm{~mL}$ of acidified methanol $10 \%$ with $\mathrm{HCl} 1 \mathrm{~N}$ using a vortex shaker for $60 \mathrm{~s}$ before being incubated for $60 \mathrm{~min}$ at $85^{\circ} \mathrm{C}$ to extract hydrolysable polyphenolics following the procedure described by Hartzfeld et al. [32] and Lei et al. [33] with slight modifications. They were then centrifuged at $4000 \mathrm{rpm}$ for $15 \mathrm{~min}$ at $4{ }^{\circ} \mathrm{C}$ and evaporated to dryness in a rotary evaporator at $40{ }^{\circ} \mathrm{C}$ before being reconstituted with the supernatant obtained in the previous step, resulting in a crude extract containing both free and hydrolysable phenolic fractions. Crude extracts were subjected to the solid phase extraction (SPE) treatment with the Oasis HLB cartridge ( $200 \mathrm{mg}, 3 \mathrm{cc}, 30 \mu \mathrm{m}$ particle size) filtered through a $0.45 \mu \mathrm{m}$ membrane filter and kept at $-18{ }^{\circ} \mathrm{C}$ until analysis. The final supernatant obtained was used for the estimation of total phenolic content, 2,2-diphenyl-1-picrylhydrazyl (DPPH), ferric reducing antioxidant power (FRAP), and for polyphenolic compound profiling by HPLC-ESI-CID-MS (QTOF).

The total phenolic content (TPC) in meat and animal diets was determined using the Folin-Ciocalteu reagent following the modified method of Singleton et al. [34]. FolinCiocalteu was added $(0.5 \mathrm{~mL})$ to $0.5 \mathrm{~mL}$ final extract, followed by the addition of $0.5 \mathrm{~mL}$ sodium carbonate solution $(7.5 \%)$ and $7 \mathrm{~mL}$ of distilled water. The reaction mixture was vortexed before being incubated for $1 \mathrm{~h}$ in the dark. The absorbance of phenolic content was measured spectrophotometrically with a UV-20 Onda Spectrophotometer at $760 \mathrm{~nm}$. The quantification of phenolics was based on the standard curve generated with the use of gallic acid and expressed as mg of gallic acid equivalent/100 $\mathrm{g}$ dry weight.

The DPPH radical scavenging activity was estimated according to Llorach et al. [35]. Results were expressed as $\mu \mathrm{mol}$ of Trolox equivalents $/ 100 \mathrm{~g}$ dry weight after measuring the absorbance of the DPPH radical-extract complex and the Trolox standard curve $(0-60 \mu \mathrm{M})$ at $515 \mathrm{~nm}$.

The FRAP assay was performed according to Thaipong et al. [36] with some modifications. The stock solutions included a $23 \mathrm{mM}$ acetate buffer $\left(3.13 \mathrm{~g} \mathrm{C}_{2} \mathrm{H}_{3} \mathrm{NaO}_{2} \cdot 3 \mathrm{H}_{2} \mathrm{O}\right.$ and $16 \mathrm{~mL}$ acetic acid), pH 3.6, $10 \mathrm{mM}$ TPTZ (2, 4, 6 tripyridyl-s-triazine) solution in $40 \mathrm{mM}$ $\mathrm{HCl}$, and $20 \mathrm{mM}$ ferric chloride hexahydrate solution. The fresh working solution was prepared by mixing $25 \mathrm{~mL}$ acetate buffer, $2.5 \mathrm{~mL}$ TPTZ solution, and $2.5 \mathrm{~mL}$ ferric chloride hexahydrate solution and then warmed at $37^{\circ} \mathrm{C}$ before using. Samples of the meat extract $(120 \mu \mathrm{L})$ were allowed to react with $900 \mu \mathrm{L}$ of the FRAP solution for $20 \mathrm{~min}$ in the dark 
condition. Readings of the coloured product [ferrous tripyridyltriazine complex] were then taken at $595 \mathrm{~nm}$. The standard curve was linear between 50 and $1000 \mu \mathrm{M}$ Trolox. Results were expressed in $\mu \mathrm{mol}$ of Trolox equivalents $/ 100 \mathrm{~g}$ dry weight. Additional dilution was needed if the FRAP value measured was over the linear range of the standard curve.

\subsection{Evaluation of $p H$}

The $\mathrm{pH}$ was determined in minced left hind leg meat at 0,4 , and 6 days of refrigerated storage $\left(4^{\circ} \mathrm{C}\right)$ in overwrap using an XSPH7 + DHS portable $\mathrm{pH}$-meter with a penetration probe.

\subsection{Thiobarbituric Acid Reactive Substances Assay}

Lipid oxidation was quantified using the thiobarbituric acid reactive substances (TBARs) assay according to Pfalzgraf et al. [37]. Meat samples weighing $10 \mathrm{~g} \pm 0.02$ were homogenised with $20 \mathrm{~mL}$ of trichloroacetic acid (10\%) using an Ultra-Turrax T25 (Janke \& Kunkel, Staufen, Germany). Samples were centrifuged (Gyrozen 1248R, Daejeon, Korea) at $4000 \mathrm{rpm}$ for $30 \mathrm{~min}$ and the supernatants filtered through qualitative paper (F1093 grade; Chmlab, Barcelona, Spain). Two milliliters of the filtrates were taken in duplicates and mixed with $2 \mathrm{~mL}$ of thiobarbituric acid, homogenized, and incubated for $20 \mathrm{~min}$ in a water bath at $97^{\circ} \mathrm{C}$. Absorbance was measured at $532 \mathrm{~nm}$. The results were expressed as $\mathrm{mg}$ of malondialdehyde (MDA) $/ \mathrm{kg}$ of the sample, using a standard curve that covered the concentration range of 1 to $10 \mathrm{mM}$ 1,1,3,3-tetramethoxypropane. Lipid oxidation assays were performed at 0,4 , and 6 days of storage at $4{ }^{\circ} \mathrm{C}$, in overwrap samples.

\subsection{Total Volatile Basic Nitrogen Assay}

The total volatile basic nitrogen (TVB-N) assay was carried out according to the protocol described in the European Union Commission Regulation 2074/2005, Chapter III, "Determination of the concentration of TVB-N in fish and fish products" [38] with some modifications. A $2 \mathrm{~g}$ sample of homogenised minced rabbit meat was blended with $90 \mathrm{~mL}$ of $6 \%$ perchloric acid solution using an Ultraturrax (IKA, Staufen, Germany). The extract obtained was filtered, and $50 \mathrm{~mL}$ aliquots were dispensed into an apparatus for steam distillation. Analyses were run in triplicate. The $50 \mathrm{~mL}$ of filtrate was rendered alkaline with $20 \%$ hydroxide and distilled in a Udk 129 Kjeltec Distillation Unit (VELP Scientifica Srl, Usmate (MB) - Italy. The titration was carried out with $0.01 \mathrm{~N} \mathrm{HCl}$, and the results were reported as $\mathrm{mg} \mathrm{N}_{2}$ non-protein/100 $\mathrm{g}$ fresh rabbit meat.

\subsection{Statistical Analyses}

Statistical analyses were performed using the SPSS software package (version 26.0). Analysis of variance was used to evaluate productive performance traits, fat percentage, fatty acid profile, total phenolic content, and DPPH and FRAP of rabbit meat, according to the dietary treatment (CON vs. GPD) as the source of variation. TBARs, TVB-N, and $\mathrm{pH}$ data on meat were processed using a general linear model, with diet, days of storage and their interaction as fixed factors. Marginal mean values and standard error were reported. A probability value of $p \leq 0.05$ was considered statistically significant. Tukey's multiple range test was used to determine whether there were significant differences between the mean values of storage days.

\section{Results and Discussion}

\subsection{Productive Performance}

Performance traits for rabbits fattened with grape pomace supplementation and a commercial diet are presented in Table 2. No significant differences between the two diets were found for periodically assessed live weight $(p>0.05)$, but the feed conversion rate was higher and carcass weight and yield were lower for the grape pomace diet compared to the control diet $(p \leq 0.05)$. 
Supporting our results, those of Motta-Ferreira et al. [4] showed a similar daily gain and increasing feed conversion rates, when alfalfa hay was replaced with grape pomace in increasing proportions (from 0 to $300 \mathrm{~g} / \mathrm{kg}$ total weight). Likewise, Eid [9] showed similar weight gains in rabbit bucks of 6 months of age that were fed a basal diet or a diet supplemented with 10 or $20 \%$ grape pomace (both being isonitrogenous and isocaloric). The results of our study are probably related to the fact that grape pomace is a highly lignified source of fibre, which could increase the transit time of digesta and reduce nutrient digestibility [39], stimulating feed intake while achieving a similar growth rate. In a previous study, the increased levels of fat provided by grape pomace may encourage consumption [4], but in our study there was little difference in ether extract between the diets (Table 1).

Generally, a diet that enhances feed intake is assumed to improve carcass yield by reducing caecum content weight [40], however, and in line with our results, the study by Margüenda et al. [41] found lower carcass yields when rabbits were fed a high fibre straw diet compared to a low fibre straw diet, but no differences in digestive tract weight were observed. A recent study concludes that the effect of lignin rich diets on carcass yields is not consistent and that interaction factors should be considered [42], whereas the effect of high soluble fibre on reducing carcass yield is more reliable [43].

Table 2. Marginal means and SE for productive traits of rabbits fattened with a commercial (medicated plus withdrawal feeds) or an alternative (unmedicated feed with $20 \%$ addition of grape pomace) feeding regime.

\begin{tabular}{|c|c|c|c|c|}
\hline Variable & Control Diet & Grape Pomace Diet & SE & $p$-Value \\
\hline Initial age (days) & 35 & 35 & & \\
\hline Days of fattening & 30 & 30 & & \\
\hline Final age (days) & 65 & 65 & & \\
\hline Initial live weight (kg) & 7.40 & 6.36 & 0.41 & 0.146 \\
\hline Live weight (kg) week 1 & 9.72 & 8.48 & 0.47 & 0.140 \\
\hline Live weight (kg) week 2 & 11.93 & 10.71 & 0.51 & 0.167 \\
\hline Live weight $(\mathrm{kg})$ week 3 & 14.26 & 12.90 & 0.55 & 0.157 \\
\hline Live weight $(\mathrm{kg})$ at slaughter & 16.50 & 14.83 & 0.58 & 0.115 \\
\hline Feed conversion * & 3.38 & 3.66 & 0.10 & 0.001 \\
\hline Carcass weight (kg) & 10.22 & 8.97 & 0.34 & 0.050 \\
\hline Carcass yield $(\%)$ & 61.97 & 60.18 & 0.35 & 0.021 \\
\hline
\end{tabular}

Group data from six animals per cage (three cages per treatment). * Diet $(\mathrm{kg})$ per live weight gain $(\mathrm{kg})$. SE: Standard error.

\subsection{Fat Percentage and Fatty Acid Composition of the Meat}

The fat percentage and the fatty acid composition of the intramuscular fat of rabbits that were fed the control diet (CON) or the alternative diet containing $20 \%$ grape pomace (GPD) is reported in Table 3. The inclusion of grape pomace increased the fat percentage (2.01 vs. 1.54) and modified the fatty acid composition of the Longisimuss dorsi (LD) muscle. In a previous study, grape pomace inclusion in fattening diets increased the body fat content of rabbits slaughtered at $2 \mathrm{~kg}$ live weight and the results were related to increased ether extract and reduced digestible protein to digestible energy ratio and the increased feed intake achieved with the grape by-product enriched diets [4], and all these might play a part in explaining the differences in our study, as well.

A higher percentage of intramuscular fat suggests a higher proportion of triacylglycerol and a lower proportion of phospholipids, which in rabbits means increased C14:0 and C16:0 and monounsaturated fatty acids (MUFA), and decreased polyunsaturated fatty acids (PUFA) (except C18:3 n-3) and C18:0 fatty acids percentages [44], but all these changes were not evident in the GPD group (Table 3). Therefore, it was diet composition more than fat percentage that was responsible for the differences found in the fatty acid profile of LD samples, as was also observed in a study of rabbit diets supplemented with artichoke bracts [5]. The fatty acid composition of the diet is reflected directly in essential fatty acids, 
such as linoleic and linolenic fatty acids, but it could also affect the accumulation and synthesis of other fatty acids $[45,46]$ in the animals.

Table 3. Marginal means and SE for fat percentage, fatty acid profile (\% of total fatty acids), and fatty acid ratios and nutritional indices of the Longissimus dorsi muscle of rabbits fattened with a commercial (medicated plus withdrawal feeds) or an alternative (unmedicated feed with $20 \%$ addition of grape pomace) feeding regime.

\begin{tabular}{ccccc}
\hline & Control Diet & Grape Pomace Diet & SE & $p$-Value \\
\hline Fat & 1.54 & 2.01 & 0.14 & 0.026 \\
SFA & 42.4 & 39.8 & 0.29 & $\leq 0.001$ \\
C10:0 & 0.26 & 0.19 & 0.02 & 0.010 \\
C12:0 & 1.71 & 1.38 & 0.05 & $\leq 0.001$ \\
C14:0 & 4.17 & 3.47 & 0.12 & $\leq 0.001$ \\
C15:0 & 0.47 & 0.44 & 0.01 & 0.022 \\
C16:0 & 28.2 & 26.8 & 0.30 & 0.002 \\
C17:0 & 0.44 & 0.45 & 0.01 & 0.439 \\
C18:0 & 6.66 & 6.71 & 0.14 & 0.809 \\
C21:0 & 0.50 & 0.42 & 0.03 & 0.027 \\
C24:0 & 0.48 & 0.36 & 0.03 & 0.007 \\
MUFA & 29.3 & 30.0 & 0.43 & 0.252 \\
C14:1 $n-5$ & 0.22 & 0.16 & 0.02 & 0.011 \\
C16:1 $n-7$ & 2.55 & 1.99 & 0.17 & 0.024 \\
C18:1 $n-7 c$ & 1.29 & 1.22 & 0.04 & 0.184 \\
C20:1 $n-9$ c & 25.0 & 26.4 & 0.35 & 0.008 \\
PUFA & 0.28 & 0.27 & 0.01 & 0.911 \\
C16:3 $n-4$ & 27.8 & 29.8 & 0.65 & 0.037 \\
C18:2 $n-6 c$ & 0.57 & 0.54 & 0.04 & 0.519 \\
C18:3 $n-3$ & 20.7 & 23.5 & 0.33 & $\leq 0.001$ \\
C20:4 $n-6$ & 1.12 & 0.96 & 0.03 & 0.001 \\
C22: $n$-6 & 4.11 & 3.60 & 0.28 & 0.210 \\
C22:6 $n-3$ & 1.15 & 1.08 & 0.08 & 0.540 \\
$n-3$ PUFA & 0.17 & 0.15 & 0.01 & 0.307 \\
$n-6$ PUFA & 1.29 & 1.12 & 0.02 & $\leq 0.001$ \\
$n-6 / n-3$ & 26.0 & 28.2 & 0.61 & 0.016 \\
PUFA/SFA & 20.3 & 25.4 & 0.73 & $\leq 0.001$ \\
PI & 0.66 & 0.75 & 0.02 & 0.003 \\
AI & 48.2 & 48.0 & 0.82 & $\leq 0.001$ \\
TI & 0.83 & 1.14 & 0.01 & 0.01 \\
\hline
\end{tabular}

SFA: Sum of saturated fatty acids; MUFA: Sum of monounsaturated fatty acids; PUFA: Sum of polyunsaturated fatty acids; PI: Peroxidability index; AI: Atherogenicity index; TI: Thrombogenicity index. SE: Standard error.

The GPD group showed a lower percentage of saturated fatty acids (SFA), mainly due to the lower proportion of palmitic (C16:0) and myristic (C14:0) acids, and increased PUFA due to the higher proportion of linoleic acid, but a lower proportion of $\alpha$-linolenic acid, leading to PUFA/SFA and $n-6 / n-3$ ratios that were higher in the alternative diet group than in the control group (Table 3). These results are in agreement with those reported by Bennato et al. [13] in poultry meat that showed that diets containing at least $5 \%$ of grape pomace by-product induced an increase in the concentration of linoleic acid and a decrease in total SFA, increasing the PUFA/SFA ratio.

Our findings specifically suggest that GPD plays a positive role in increasing the PUFA/SFA ratio but involves an undesirable rise of the $n-6 / n-3$ ratio compared to the control diet, as a consequence of the high linoleic acid percentage. Both treatments achieve the level recommended by the Department of Health [47] for the PUFA/SFA ratio, but not the $n-6 / n-3$ ratio, these being $>0.4$ and $<4$, respectively.

Other nutritional indices are the atherogenic index (AI) and the thrombogenic index (TI), which, the higher they are the higher the risk is of developing atherosclerosis and platelet aggregation in humans [19]. In our study, these two indices were lower in the meat 
from the experimental diet in comparison with the control diet, as is the case in previous studies with other polyphenol-rich feed ingredients, since, additionally, they provide fatty acids that improve the two aforementioned indices $[6,48]$. The single fatty acids that played a greater role in this improvement were the reduction of C14:0 and C16:0 and the increase of C18:6n-6 in the meat of the GPD group.

\subsection{Identification of Phenolic Compounds}

Table 4 shows that among the different feed samples 42 phenolic compounds were identified, 38 of them appeared in the grape pomace by-product of which 14 compounds belonged to the flavanol group, mainly procyanidins and their derivatives and catechin 3-O-gallate, six compounds correspond to the flavonols group, seven were anthocyanins, eight resveratrol derivatives and ellagic acid belonging to phenolic acids. The grape pomace by-product compounds identified were also detected in previous studies of grape derivatives [22-31,49].

Table 4. HPLC-ESI-QTOF profile in negative and positive ionization mode (IM) of phenolic compounds identified in the control diet (CON), the grape pomace diet (GPD), the by-product grape pomace (GP), and in meat from the two groups.

\begin{tabular}{|c|c|c|c|c|c|c|c|c|c|}
\hline $\mathbf{N}^{\circ}$ & $\mathbf{R}_{\mathbf{t}}$ & Compound Name & IM & $\operatorname{MS}(m / z)$ & MS/MS $(m / z)$ & $\mathrm{CON}$ & GPD & GP & Meat \\
\hline 1 & 0.3 & Procyanidin trimer gallate & $(\mathrm{M}-\mathrm{H})^{-}$ & 1017.19 & $\begin{array}{c}865,729,577,575,441,125 \\
407,289,169\end{array}$ & - & $+{ }^{*}$ & + & - \\
\hline 2 & 0.3 & Chlorogenic acid & $(\mathrm{M}-\mathrm{H})^{-}$ & 353.0863 & 191 & + & + & - & - \\
\hline 3 & 0.3 & Cyanidin 3,5-O-diglucoside & $(\mathrm{M}+\mathrm{H})^{+}$ & 579.1408 & 287 & - & + & + & - \\
\hline 4 & 1.0 & Procyanidin A dimer & $(\mathrm{M}-\mathrm{H})^{-}$ & 575.1178 & $125,113,175,289$ & - & - & + & - \\
\hline 5 & 2.7 & Procyanidin B dimer & $(\mathrm{M}-\mathrm{H})^{-}$ & 577.1297 & $175,113,407$ & + & + & + & - \\
\hline 6 & 4.2 & Procyanidin B trimer & $(\mathrm{M}-\mathrm{H})^{-}$ & 865.1949 & $577,407,125,289$ & - & $+^{*}$ & + & - \\
\hline 7 & 5.3 & Malvidin 3-O-galactoside & $(\mathrm{M}+\mathrm{H})^{+}$ & 493.1349 & & - & - & + & - \\
\hline 8 & 5.4 & Procyanidin B trimer & $(\mathrm{M}-\mathrm{H})^{-}$ & 865.1920 & $\begin{array}{c}729,575,113,175,289,287 \\
125\end{array}$ & - & + & + & - \\
\hline 9 & 5.7 & Procyanidin B dimer gallate & $(\mathrm{M}-\mathrm{H})^{-}$ & 729.1438 & $577,175,113,425,407,289$ & - & $+*$ & + & - \\
\hline 10 & 5.8 & Procyanidin A dimer gallate & $(\mathrm{M}-\mathrm{H})^{-}$ & 729.1326 & $575,175,113,125,289,449$ & - & $+^{*}$ & + & - \\
\hline 11 & 6.1 & Procyanidin A dimer & $(\mathrm{M}-\mathrm{H})^{-}$ & 575.1172 & $175,113,289$ & - & + & + & - \\
\hline 12 & 6.6 & Catechin 3-O-gallate & $(\mathrm{M}-\mathrm{H})^{-}$ & 441.0783 & $169,125,289$ & - & + & + & - \\
\hline 13 & 6.7 & Myricetin O-dihexoside & $(\mathrm{M}-\mathrm{H})^{-}$ & 641.1413 & $297,191,125$ & + & + & + & - \\
\hline 14 & 6.8 & Procyanidin A dimer digallate & $(\mathrm{M}-\mathrm{H})^{-}$ & 881.1572 & & - & - & + & - \\
\hline 15 & 6.8 & Malvidin 3-O-hexoside-acetaldehyde & $(\mathrm{M}+\mathrm{H})^{+}$ & 517.1329 & & - & - & + & - \\
\hline 16 & 7.0 & Ellagic acid & $(\mathrm{M}-\mathrm{H})^{-}$ & 300.9990 & & + & + & + & - \\
\hline 17 & 7.1 & Delphinidin 3-O-hexuronide & $(\mathrm{M}-\mathrm{H})^{-}$ & 479.0810 & & - & - & + & - \\
\hline 18 & 7.2 & Quercetin 3-O-hexuronide & $(\mathrm{M}-\mathrm{H})^{-}$ & 477.0645 & 301 & + & + & + & - \\
\hline 19 & 7.2 & Procyanidin A dimer & $(\mathrm{M}-\mathrm{H})^{-}$ & 575.1121 & 289,125 & - & + & + & - \\
\hline 20 & 8.1 & Procyanidin A dimer & $(\mathrm{M}-\mathrm{H})^{-}$ & 575.1189 & $285,125,175,113$ & - & + & + & - \\
\hline 21 & 8.4 & Myricetin & $(\mathrm{M}-\mathrm{H})^{-}$ & 317.0322 & 151,137 & - & + & + & - \\
\hline 22 & 8.5 & Syringetin 3-O-hexoside & $(\mathrm{M}-\mathrm{H})^{-}$ & 507.1135 & 344 & - & - & + & - \\
\hline 23 & 8.6 & Malvidin 3-O-hexoside derivative & $(\mathrm{M}+\mathrm{H})^{+}$ & 517.1296 & & + & + & - & - \\
\hline 24 & 8.7 & Procyanidin A dimer gallate & $(\mathrm{M}-\mathrm{H})^{-}$ & 729.1408 & 407,289 & - & - & + & - \\
\hline 25 & 8.7 & Chlorogenic acid hexoside & $(\mathrm{M}-\mathrm{H})^{-}$ & 515.1115 & $353,179,173$ & + & + & - & - \\
\hline 26 & 9.3 & Malvidin 3-O-(6"-p-coumaroyl)-glucoside & $(\mathrm{M}+\mathrm{H})^{+}$ & 639.1637 & & - & + & + & - \\
\hline 27 & 9.7 & Malvidin 3-O-(6" - -p-coumaroyl)-exoside & $(\mathrm{M}+\mathrm{H})^{+}$ & 639.1674 & & - & + & + & - \\
\hline 28 & 10.2 & Quercetin & $(\mathrm{M}-\mathrm{H})^{-}$ & 301.0382 & $151,121,179$ & + & + & + & - \\
\hline 29 & 10.6 & Peonidin 3-O-(6" -p-coumaroyl)-hexoside & $(\mathrm{M}+\mathrm{H})^{+}$ & 609.1559 & & - & - & + & - \\
\hline 30 & 11.2 & Resveratrol dimer & $(\mathrm{M}-\mathrm{H})^{-}$ & 453.1291 & & - & - & + & - \\
\hline 31 & 11.4 & Resveratrol tetramer & $(\mathrm{M}-\mathrm{H})^{-}$ & 905.2565 & $359,451,717$ & - & - & + & - \\
\hline 32 & 11.6 & Resveratrol dimer & $(\mathrm{M}-\mathrm{H})^{-}$ & 453.1318 & & - & + & - & - \\
\hline 33 & 11.9 & Kaempferol & $(\mathrm{M}-\mathrm{H})^{-}$ & 285.0422 & $136,133,273$ & + & + & + & - \\
\hline 34 & 12.0 & Resveratrol dimer & $(\mathrm{M}-\mathrm{H})^{-}$ & 453.1309 & 369 & - & + & + & - \\
\hline 35 & 12.3 & Resveratrol tetramer & $(\mathrm{M}-\mathrm{H})^{-}$ & 905.2454 & & - & - & + & - \\
\hline 36 & 12.4 & Resveratrol trimer & $(\mathrm{M}-\mathrm{H})^{-}$ & 679.1972 & & - & + & - & - \\
\hline 37 & 12.6 & Resveratrol trimer & $(\mathrm{M}-\mathrm{H})^{-}$ & 679.1898 & & - & + & + & - \\
\hline 38 & 12.8 & Resveratrol trimer & $(\mathrm{M}-\mathrm{H})^{-}$ & 679.1950 & 437 & - & + & + & - \\
\hline 39 & 13.0 & Resveratrol trimer & $(\mathrm{M}-\mathrm{H})^{-}$ & 679.1956 & & - & + & + & - \\
\hline 40 & 13.3 & Resveratrol trimer & $(\mathrm{M}-\mathrm{H})^{-}$ & 679.1913 & & - & + & + & - \\
\hline 41 & 13.3 & Quercetin 3-O-galactoside & $(\mathrm{M}-\mathrm{H})^{-}$ & 463.0915 & & + & - & - & - \\
\hline 42 & 15.9 & Procyanidin B dimer & $(\mathrm{M}-\mathrm{H})^{-}$ & 577.3678 & & - & - & + & - \\
\hline
\end{tabular}

$\mathrm{R}_{\mathrm{t}}$ : Retention time (min), + detected compound and undetected compound, * appear as procyanidin B dimer with $m / z 577.123$ or procyanidin A dimer with $m / z 575.1153$. 
As was expected, in the grape pomace diet most of the phenolic compounds present in the by-product were found, with the exception of procyanidin A dimer digallate, syringetin 3-O-hexoside, procyanidin A dimer gallate, resveratrol tetramer, malvidin 3-O-galactoside, malvidin 3-O-hexoside-acetaldehyde, delphinidin 3-O-hexuronide, and peonidin 3-O-(6 $6^{\prime \prime}$ p-coumaroyl)-hexoside.

On the other hand, three compounds: Chlorogenic acid, chlorogenic acid hexoside, and malvidin 3-O-hexoside derivative were detected in the two diets, but not in the grape pomace by-product, whereas other six compounds were detected in all the feed samples: Procyanidin B dimer $\left(\mathrm{R}_{\mathrm{t}} 2.7\right)$, myricetin $\mathrm{O}$-dihexoside, ellagic acid, quercetin 3-O-hexuronide, quercetin, and kaempferol. However, as shown in Figure S1, these last two compounds, quercetin (peak 28) and kaempferol (peak 33), were found in higher concentrations in the GPD and even more so in the grape by-product. These two flavonols have also been reported in various wine grape varieties [50]. Finally, quercetin 3-Ogalactoside was only detected in the control diet (Table 4).

None of the phenolic compounds detected in feeds reported in Table 4 were detected in the meat samples. Few studies have analysed dietary phenolic compounds in meat. For example, in the study by Moniño et al. [51] eleven phenolic compounds detected in pellets fed to ewes were also detected in the meat of their suckling lambs without modification. In contrast, other studies have shown that dietary phenolic compounds can be transformed, degraded, excreted or retained in other tissues, such as the liver [52-54], and therefore, they are not detected in meat.

\subsection{Total Phenolic Content, Antioxidant Capacity, and Reducing Power}

The total phenolic content, antioxidant capacity measured as DPPH (2,2-diphenyl-1 picrylhydrazyl) free radical scavenging activity, and reducing power measured by the FRAP method (ferric-reducing ability) in hind leg rabbit meat were not affected significantly $(p \leq 0.05)$ by dietary grape pomace supplementation (Table 5). Although it is difficult to compare results from different studies due to divergences in the extraction and analytical methods, our results are in agreement with those of Mancini et al. [55] and North et al. [56], in that no effect on antioxidant properties was observed in the meat of rabbits offered diets supplemented with ingredients rich in polyphenols (4 or $8 \mathrm{~g}$ of Zingiber officinale Roscoe (ginger) powder in $100 \mathrm{~g}$ of feed or with $2 \mathrm{~g}$ quercetin $/ \mathrm{kg}$ feed, respectively). However, our results contrast to those of Perna et al. [6] and Menchetti et al. [57], who reported greater total phenolic content and antioxidant capacity in the meat of rabbits that were fed diets including cauliflower and goji berries, respectively, compared to the control groups. Regarding grape pomace, Goñi et al. [12] showed that a dietary inclusion rate of up to $30 \mathrm{~g} / \mathrm{kg}$ increased antioxidant activity in diet, excreta, and meat in broilers. Zhao et al. [15] showed that the total antioxidant capacity, glutathione peroxidase 4 , and superoxide dismutase activity increased in ram lambs fed with diets containing wine grape pomace (with levels of $0 \%, 5 \%$, and $10 \%$ ).

The DPPH and FRAP levels of the grape pomace by-product used in our study are similar to the levels reported by Rockenbach et al. [50], but the TPC is lower than the mean values they reported (from 3200 to $7400 \mathrm{mg}$ gallic acid equivalent per $100 \mathrm{~g}$ of dry weight, depending on the grape varieties). By including $20 \%$ of this by-product, TPC values increased 119\%, DPPH 300\%, and FRAP 98\% in the pellet diets of the present study (Table 1). Despite the differences in the two diets (control vs. grape pomace), no significant effect was found on the aforementioned parameters (Table 5), either in meat or lipid oxidation (TBARs, Table 6). The lack of effect in the GPD group may be due to the loss of antioxidant properties after digestion or to a low/null deposition of antioxidants in the meat. Dabbou et al. [48] found an increase in antioxidant activity in the kidney and liver of growing rabbits, but a similar degree of lipid oxidation in the meat when supplementing diets with bilberry pomace vs. control diets. With grape pomace added in feedstuffs, Eid [9] found antioxidant effects of this by-product in rabbit buck semen, which 
means that the antioxidant properties can be transferred to the animal, but maybe not to a similar extent to the meat.

Table 5. Marginal means and SE for total phenolic content (TPC), antioxidant capacity (DPPH), and reducing power (FRAP) of hind leg meat of rabbits fattened with a commercial (medicated plus withdrawal feeds) or an alternative (unmedicated feed with $20 \%$ addition of grape pomace) feeding regime.

\begin{tabular}{ccccc}
\hline & Control Diet & Grape Pomace Diet & SE & $p$-Value \\
\hline TPC $($ mg gallic acid equivalent/100 g d.w.) & 141.9 & 145.5 & 6.90 & 0.325 \\
DPPH ( $\mu$ mol of Trolox equivalents/100 g d.w.) & 93.95 & 98.09 & 2.93 & 0.720 \\
FRAP $(\mu$ mol of Trolox equivalents/100 g d.w.) & 156.1 & 163.6 & 6.47 & 0.417 \\
\hline
\end{tabular}

DPPH: Free radical 2,2-diphenyl-1-picrylhydrazyl; FRAP: Ferric reducing antioxidant power; d.w.: Dry weight.

Table 6. Marginal means and (SE) for $\mathrm{pH}$, thiobarbituric acid reactive substance (TBARs), and total volatile basic nitrogen (TVB-N) of minced overwrapped hind leg meat stored for 6 days at $4{ }^{\circ} \mathrm{C}$, from rabbits fattened with a commercial (medicated plus withdrawal feed) or an alternative (unmedicated feed with $20 \%$ addition of grape pomace) feeding regime.

\begin{tabular}{|c|c|c|c|c|c|c|c|}
\hline \multirow{2}{*}{ Parameter } & \multirow{2}{*}{ Storage } & \multicolumn{2}{|c|}{ Diet } & \multirow[b]{2}{*}{ Mean } & \multicolumn{3}{|c|}{$p$-Value } \\
\hline & & Control & Grape Pomace & & Diet & Storage & Diet X Storage \\
\hline \multirow{4}{*}{$\mathrm{pH}$} & Day 0 & 5.91 & 5.94 & $5.93(0.01)$ & & & \\
\hline & Day 4 & 5.92 & 5.99 & $5.96(0.02)$ & & & \\
\hline & Day 6 & 5.97 & 5.96 & $5.96(0.01)$ & & & \\
\hline & Mean & $5.93(0.01)$ & $5.96(0.01)$ & & 0.051 & 0.100 & 0.132 \\
\hline \multirow{4}{*}{$\begin{array}{l}\text { TBARs (mg } \\
\text { MDA/kg) }\end{array}$} & Day 0 & 0.10 & 0.10 & $0.10 b(0.05)$ & & & \\
\hline & Day 4 & 0.31 & 0.35 & $0.33 a(0.06)$ & & & \\
\hline & Day 6 & 0.40 & 0.44 & $0.42 \mathrm{a}(0.05)$ & & & \\
\hline & Mean & $0.27(0.04)$ & $0.30(0.04)$ & & 0.652 & $\leq 0.001$ & 0.958 \\
\hline \multirow{4}{*}{$\begin{array}{l}\text { TVB-N (mg } \\
\text { N/100 g) }\end{array}$} & Day 0 & 31.31 & 28.00 & $29.66 c(1.02)$ & & & \\
\hline & Day 4 & 35.45 & 33.36 & $34.41 b(1.01)$ & & & \\
\hline & Day 6 & 46.17 & 39.83 & 43.00a (1.71) & & & \\
\hline & Mean & 37.64 (1.05) & $33.73(1.06)$ & & 0.010 & $\leq 0.001$ & 0.565 \\
\hline
\end{tabular}

a, b, c Marginal means with different letters in the same column differ significantly (Tukey test). SE: Standard error.

\subsection{Evaluation of $p H$}

Regarding the $\mathrm{pH}$ in minced meat from the hind leg, our data (Table 6) are within the range of what other studies have reported for that cut [58-60]. No effect of diet or of storage time was found (Table 6). These results are in agreement with the review of Hulot and Ouhayoun [60] who stated that diet usually does not affect the $\mathrm{pH}$, especially when the growth rate is not affected. Likewise, Perna et al. [6] and North et al. [56] did not find any significant influence of dietary cauliflower and quercetin on rabbit meat $\mathrm{pH}$. With regards to the evolution of $\mathrm{pH}$ during refrigerated storage, our results are in contrast to general findings $[56,60,61]$ which report an increase in $\mathrm{pH}$ over time due to protein deamination.

\subsection{Lipid Oxidation}

Although the PUFA/SFA ratio was higher in meat samples from GPD, the peroxidability index (PI) showed the same susceptibility to lipid oxidation between dietary treatments (Table 3). In addition, the lack of any difference in the antioxidant properties of the meat from the two treatments (Table 5), shows that the malondialdehyde concentration found in meat from the two diets is similar (Table 6). However, as expected, TBARs levels increased $(p \leq 0.05)$ in minced hind leg samples stored at $4{ }^{\circ} \mathrm{C}$, from $0.10 \mathrm{mg} \mathrm{MDA} / \mathrm{kg}$ on the initial day $(\mathrm{d} 0)$ to 0.42 on the sixth day (d6). In previous studies, dietary grape pomace supplementation was able to reduce TBARs in broiler meat and patties, this inhibition being clearer the longer the storage days $[12,62]$. 


\subsection{Total Volatile Basic Nitrogen}

The total volatile basic nitrogen indicates protein and amine degradation due to microbial activity or to endogenous enzymatic action and is generally used to estimate the shelf life of fish and meat [63]. TVB-N was lower in the GPD group (Table 6), suggesting that $20 \%$ grape pomace in diets may delay spoilage in rabbit meat. Phenolic compounds in grape by-products have well-known antimicrobial effects $[8,64]$, but in the present study we could not identify them in the meat samples, making further studies necessary. The amount of TVB-N content increased significantly during refrigerated storage at $4{ }^{\circ} \mathrm{C}$, going from 29.66 on the initial day (d0) to $43.00 \mathrm{mg} / 100 \mathrm{~g}$ of meat on the sixth day (d6) (Table 6). Other studies have demonstrated that microorganisms in chicken meat raise the proteolysis degree and lead to increases in the TVB-N value $[65,66]$. In meat, unlike fish, there are no official TVB-N reference values or limits. In fresh rabbit meat, Castrica et al. [67] and Lan et al. [68] reported TVB-N mean values of 15.4 and $8.6 \mathrm{mg} / 100 \mathrm{~g}$ at day 0 to 16.3 and $23.4 \mathrm{mg} / 100 \mathrm{~g}$ at day 10 of refrigerated storage, respectively. Our results were higher than the findings of these previous studies but in the present experiment thawed rabbit meat was minced and stored in refrigerated conditions. Frozen storage significantly worsens protein degradation, increasing basic volatile nitrogen due to protein deamination [69].

\section{Conclusions}

Adding $20 \%$ grape pomace to the diet did not affect the live weights of rabbits during the fattening period, however it reduced the feed conversion rate and carcass weight and yield. The resultant meat had a higher intramuscular fat percentage and a beneficial fatty acid composition of the Longissimus dorsi with respect to the polyunsaturated/saturated fatty acid ratio and the lower atherogenicity and thrombogenicity risks. However, the $n$ $6 / n-3$ ratio was found to be unfavourable. Several phenolic compounds, such as quercetin, kaempferol, myricetin, and resveratrol derivatives, were highlighted in the diet with added grape pomace, likewise, the total phenolic content, antioxidant capacity, and reducing power were higher compared to the control diet. However, these phenolic compounds were not detected in the meat, and the two treatments, showed similar levels of antioxidant capacity and reducing power. Regarding meat shelf life, dietary inclusion of grape pomace apparently decreased protein spoilage of rabbit meat, but no effect on lipid oxidation was found in minced hind leg meat stored up to 6 days.

Finally, the present study shows that grape pomace is a suitable ingredient for use in fattening rabbit diets and could help reduce the use of medical products in animal nutrition and further the sustainability of farming systems, however there are other aspects such as feed costs that must be taken into consideration.

Supplementary Materials: The following are available online at https: / www.mdpi.com/article / 10.3390/antiox10050795/s1. Figure S1: HPLC-ESI-QTOF chromatograms of phenolic compounds identified in the control diet (CON), the grape pomace diet (GPD), the by-product grape pomace $(\mathrm{GP})$, and meat from the two groups (selected ion profiles in negative ionization).

Author Contributions: Conceptualization, G.A.M. and V.C.R.; methodology, G.A.M., V.C.R., D.G., and J.B.C.; formal analysis, M.D.B., D.G., J.V.R., M.B., J.L.O., V.C.R., and J.B.C.; investigation, G.A.M., V.C.R., and M.D.B.; resources, G.A.M. and V.C.R.; data curation, V.C.R., G.A.M., J.V.R., and M.D.B.; writing—original draft preparation, M.D.B.; writing—review and editing, V.C.R., D.G., and J.B.C.; visualization, M.D.B.; supervision, G.A.M. and V.C.R.; project administration, G.A.M.; funding acquisition, G.A.M. All authors have read and agreed to the published version of the manuscript.

Funding: This research was funded by the Spanish Ministry of Economy \& Competitiveness (MINECO, Project AGL-2016/75229-R).

Institutional Review Board Statement: Ethical review and approval were waived for this study since practices were undertaken for the purposes of recognized animal husbandry, not likely to cause pain, suffering, distress or lasting harm equivalent to, or higher than, that caused by the introduction of a needle in accordance with good veterinary practice. The care and use of animals were performed in accordance with the Spanish Policy for Animal Protection RD53/2013, which meets the European 
Union Directive 2010/63 on the protection of animals used for experimental and other scientific purposes.

Informed Consent Statement: Not applicable.

Data Availability Statement: Data is contained within the article and supplementary material.

Acknowledgments: The authors are grateful to Beatriz Díaz Rica from the Institute of Food Science, Technology and Nutrition (ICTAN, Madrid) for her help in the fatty acid analyses. The authors wish to thank Ana de Prado for her technical assistance in the laboratory. We also thank Julie Cohen for revising the English.

Conflicts of Interest: The authors declare no conflict of interest.

\section{References}

1. Dalle Zotte, A.; Szendro, Z. The role of rabbit meat as functional food. Meat Sci. 2011, 88, 319-331. [CrossRef] [PubMed]

2. Belaunzaran, X.; Lavín, P.; Barron, L.J.R.; Mantecón, A.R.; Kramer, J.K.G.; Aldai, N. An assessment of the fatty acid composition of horse-meat available at the retail level in northern Spain. Meat Sci. 2017, 124, 39-47. [CrossRef]

3. Wood, J.D.; Richardson, R.I.; Nute, G.R.; Fisher, A.V.; Campo, M.M.; Kasapidou, E.; Sheard, P.R.; Enser, M. Effects of fatty acids on meat quality: A review. Meat Sci. 2004, 66, 21-32. [CrossRef]

4. Motta Ferreira, W.; Fraga, M.J.; Carabaño, R. Inclusion of grape pomace, in substitution for alfalfa hay, in diets for growing rabbits. Anim. Sci. J. 1996, 63, 167-174. [CrossRef]

5. Dabbou, S.; Gasco, L.; Gai, F.; Zoccarato, I.; Rotolo, L.; Dabbou Fekih, S.; Brugiapaglia, A.; Helal, A.N.; Peiretti, P.G. Dried artichoke bracts in rabbit nutrition: Effects on the carcass characteristics, meat quality and fatty-acid composition. Animal 2014, 8 , 1547-1553. [CrossRef]

6. Perna, A.; Simonetti, A.; Grassi, G.; Gambacorta, E. Effect of a cauliflower (Brassica oleraceae var. Botrytis) leaf powder-enriched diet on performance, carcass and meat characteristics of growing rabbit. Meat Sci. 2019, 149, 134-140. [CrossRef]

7. Dwyer, K.; Hosseinian, F.; Rod, M.R. The market potential of grape waste alternatives. J. Food Res. 2014, 3. [CrossRef]

8. Hassan, Y.I.; Kosir, V.; Yin, X.; Ross, K.; Diarra, M.S. Grape pomace as a promising antimicrobial alternative in feed: A critical review. J. Agric. Food Chem. 2019, 67, 9705-9718. [CrossRef]

9. Eid, Y.Z. Dietary grape pomace affects lipid peroxidation and antioxidative status in rabbit semen. World Rabbit Sci. 2008, 16, 157-164. [CrossRef]

10. Kafantaris, I.; Stagos, D.; Kotsampasi, B.; Hatzis, A.; Kypriotakis, A.; Gerasopoulos, K.; Makri, S.; Goutzourelas, N.; Mitsagga, C.; Giavasis, I.; et al. Grape pomace improves performance, antioxidant status, faecal microbiota and meat quality of piglets. Animal 2018, 12, 246-255. [CrossRef] [PubMed]

11. Moate, P.J.; Williams, S.R.O.; Torok, V.A.; Hannah, M.C.; Ribaux, B.E.; Tavendale, M.H.; Eckard, R.J.; Jacobs, J.L.; Auldist, M.J.; Wales, W.J. Grape marc reduces methane emissions when fed to dairy cows. J. Dairy Sci. 2014, 97, 5073-5087. [CrossRef] [PubMed]

12. Goñi, I.; Brenes, A.; Centeno, C.; Viveros, A.; Saura-Calixto, F.; Rebolé, A.; Arija, I.; Estevez, R. Effect of dietary grape pomace and vitamin E on growth performance, nutrient digestibility, and susceptibility to meat lipid oxidation in chickens. Poult. Sci. 2007, 86, 508-516. [CrossRef] [PubMed]

13. Bennato, F.; Di Luca, A.; Martino, C.; Ianni, A.; Marone, E.; Grotta, L.; Ramazzotti, S.; Cichelli, A.; Martino, G. Influence of grape pomace intake on nutritional value, lipid oxidation and volatile profile of poultry meat. Foods 2020, 9, 508. [CrossRef]

14. Yan, L.; Kim, I.H. Effect of dietary grape pomace fermented by Saccharomyces boulardii on the growth performance, nutrient digestibility and meat quality in finishing pigs. Asian-Aust. J. Anim. Sci. 2011, 24, 1763-1770. [CrossRef]

15. Zhao, J.X.; Li, Q.; Zhang, R.X.; Liu, W.Z.; Ren, Y.S.; Zhang, C.X.; Zhang, J.X. Effect of dietary grape pomace on growth performance, meat quality and antioxidant activity in ram lambs. Anim. Feed Sci. Technol. 2018, 236, 76-85. [CrossRef]

16. Association of official analytical chemists (AOAC). Official Methods of Analysis of AOAC International, 16th ed.; AOAC International: Gaithersburg, MD, USA, 1999.

17. Van Soest, P.J.; Robertson, J.B.; Lewis, B.A. Methods for dietary fiber, neutral detergent fiber, and nonstarch polysaccharides in relation to animal nutrition. J. Dairy Sci. 1991, 74, 3583-3597. [CrossRef]

18. Lee, M.R.F.; Tweed, J.K.S.; Kim, E.J.; Scollan, N.D. Beef, chicken and lamb fatty acid analysis a simplified direct bimethylation procedure using freeze-dried material. Meat Sci. 2012, 92, 863-866. [CrossRef] [PubMed]

19. Ulbricht, T.L.V.; Southgate, D.A.T. Coronary heart disease: Seven dietary factors. Lancet 1991, 338, 985-992. [CrossRef]

20. Arakawa, K.; Sagai, M. Species differences in lipid peroxide levels in lung tissue and investigation of their determining factors. Lipids 1986, 21, 769-775. [CrossRef]

21. Mena, P.; Calani, L.; Dall'Asta, C.; Galaverna, G.; García-Viguera, C.; Bruni, R.; Crozier, A.; Del Rio, D. Rapid and comprehensive evaluation of (poly)phenolic compounds in pomegranate (Punica granatum L.) juice by UHPLC-MS ${ }^{\mathrm{n}}$. Molecules 2012, $17,4821$. [CrossRef]

22. Püssa, T.; Floren, J.; Kuldkepp, P.; Raal, A. Survey of grapevine Vitis vinifera stem polyphenols by liquid chromatography-diode array detection-tandem mass spectrometry. J. Agric. Food Chem. 2006, 54, 7488-7494. [CrossRef] [PubMed] 
23. Rubilar, M.; Pinelo, M.; Shene, C.; Sineiro, J.; Uñez, M.J. Separation and HPLC-MS identification of phenolic antioxidants from agricultural residues: Almond hulls and grape pomace. J. Agric. Food Chem. 2007, 55, 10101-10109. [CrossRef] [PubMed]

24. Downey, M.O.; Rochfort, S. Simultaneous separation by reversed-phase high-performance liquid chromatography and mass spectral identification of anthocyanins and flavonols in Shiraz grape skin. J. Chromatogr. A 2008, 1201, 43-47. [CrossRef] [PubMed]

25. Samoticha, J.; Jara-Palacios, M.J.; Hernández-Hierro, J.M.; Heredia, F.J.; Wojdyło, A. Phenolic compounds and antioxidant activity of twelve grape cultivars measured by chemical and electrochemical methods. Eur. Food Res. Technol. 2018, 244, $1933-1943$. [CrossRef]

26. Pérez-Ramírez, I.F.; Reynoso-Camacho, R.; Saura-Calixto, F.; Pérez-Jiménez, J. Comprehensive characterization of extractable and nonextractable phenolic compounds by high-performance liquid chromatography-electrospray ionization-quadrupole time-of-flight of a grape/pomegranate pomace dietary supplement. J. Agric. Food Chem. 2018, 66, 661-673. [CrossRef] [PubMed]

27. Peixoto, C.M.; Dias, M.I.; Alves, M.J.; Calhelha, R.C.; Barros, L.; Pinho, S.P.; Ferreira, I.C.F.R. Grape pomace as a source of phenolic compounds and diverse bioactive properties. Food Chem. 2018, 253, 132-138. [CrossRef] [PubMed]

28. Yuzuak, S.; Ballington, J.; Xie, D.Y. HPLC-qTOF-MS/MS-based profiling of flavan-3-ols and dimeric proanthocyanidins in berries of two muscadine grape hybrids FLH 13-11 and FLH 17-66. Metabolites 2018, 8, 57. [CrossRef]

29. Wojdyło, A.; Samoticha, J.; Nowicka, P.; Chmielewska, J. Characterisation of (poly)phenolic constituents of two interspecific red hybrids of Rondo and Regent (Vitis vinifera) by LC-PDA-ESI-MS QTof. Food Chem. 2018, 239, 94-101. [CrossRef] [PubMed]

30. Šuković, D.; Knežević, B.; Gašić, U.; Sredojević, M.; Ćirić, I.; Todić, S.; Mutić, J.; Tešić, Ž. Phenolic profiles of leaves, grapes and wine of grapevine variety vranac (Vitis vinifera L.) from Montenegro. Foods 2020, 9, 138. [CrossRef]

31. Fuchs, C.; Bakuradze, T.; Steinke, R.; Grewal, R.; Eckert, G.P.; Richling, E. Polyphenolic composition of extracts from winery by-products and effects on cellular cytotoxicity and mitochondrial functions in HepG2 cells. J. Funct. Foods 2020, 70, 103988. [CrossRef]

32. Hartzfeld, P.W.; Forkner, R.; Hunter, M.D.; Hagerman, A.E. Determination of hydrolyzable tannins (gallotannins and ellagitannins) after reaction with potassium iodate. J. Agric. Food Chem. 2002, 50, 1785-1790. [CrossRef] [PubMed]

33. Lei, Z.; Jervis, J.; Helm, R.F. Use of methanolysis for the determination of total ellagic and gallic acid contents of wood and food products. J. Agric. Food Chem. 2001, 490, 1165-1168. [CrossRef] [PubMed]

34. Singleton, V.L.; Orthofer, R.; Lamuela-Raventos, R.M. Analysis of total phenols and other oxidation substrates and antioxidants by means of Folin-Ciocalteu reagent. Methods Enzymol. 1999, 299, 152-178. [CrossRef]

35. Llorach, R.; Tomás-Barberán, F.A.; Ferreres, F. Lettuce and chicory by-products as a source of antioxidant phenolic extracts. J. Agric. Food Chem. 2004, 52, 5109-5116. [CrossRef] [PubMed]

36. Thaipong, K.; Boonprakob, U.; Crosby, K.; Cisneros-Zevallos, L.; Hawkins Byrne, D. Comparison of ABTS, DPPH, FRAP, and ORAC assays for estimating antioxidant activity from guava fruit extracts. J. Food Compos. Anal. 2006, 19, 669-675. [CrossRef]

37. Pfalzgraf, A.; Frigg, M.; Steinhart, H. Alpha-tocopherol contents and lipid oxidation in pork muscle and adipose Tissue during Storage. J. Agric. Food Chem. 1995, 43, 1339-1342. [CrossRef]

38. Commission Regulation (EC). No 2074/2005 as Regards the Limit Values of Total Volatile Basic Nitrogen (TVB-N); Commission Regulation (EC): Brussels, Belgium, 2005.

39. Fraga, M.J.; Pérez de Ayala, P.; Carabaño, R.; de Blas, J.C. Effect of type of fiber on the rate of passage and on the contribution of soft feces to nutrient intake of finishing rabbits. Anim. Sci. J. 1991, 69, 1566-1574. [CrossRef]

40. Garcia, J.; Gidenne, T.; Falcao-E-Cunha, L.; de Blas, C. Identification of the main factors that influence caecal fermentation traits in growing rabbits. Anim. Res. 2002, 51, 165-173. [CrossRef]

41. Margüenda, I.; Nicodemus, N.; Vadillo, S.; Sevilla, L.; García-Rebollar, P.; Villarroel, M.; Romero, C.; Carabaño, R. Effect of dietary type and level of fibre on rabbit carcass yield and its microbiological characteristics. Livest. Sci. 2012, 145, 7-12. [CrossRef]

42. Caîsin, L.; Martínez-Paredes, E.; Ródenas, L.; Moya, V.J.; Pascual, J.J.; Cervera, C.; Blas, E.; Pascual, M. Effect of increasing lignin in isoenergetic diets at two soluble fibre levels on digestion, performance and carcass quality of growing rabbits. Anim. Feed Sci. Technol. 2020, 262. [CrossRef]

43. Xiccato, G. Feeding and meat quality in rabbits: A review. World Rabbit Sci. 2010, 7, 75-86. [CrossRef]

44. Martinez-Alvaro, M.; Blasco, A.; Hernandez, P. Effect of selection for intramuscular fat on the fatty acid composition of rabbit meat. Animal 2018, 12, 2002-2008. [CrossRef]

45. Rosenthal, M.D. Fatty acid metabolism of isolated mammalian cells. Prog. Lipid Res. 1987, 26, 87-124. [CrossRef]

46. Cobos, A.; Cambero, M.I.; Ordóñez, J.A.; De La Hoz, L. Effect of fat-enriched diets on rabbit meat fatty acid composition. J. Sci. Food Agric. 1993, 62, 83-88. [CrossRef]

47. Department of Health, London. Nutritional aspects of cardiovascular disease. Report of the cardiovascular review group committee on medical aspects of food policy. Rep. Health Soc. Subj. 1994, 46, 1-186.

48. Dabbou, S.; Gai, F.; Renna, M.; Rotolo, L.; Dabbou, S.; Kovitvadhi, C.L.A.; Brugiapaglia, A.; De Marco, M.; Helal, A.N.; Zoccarato, I.; et al. Inclusion of bilberry pomace in rabbit diets: Effects on carcass characteristics and meat quality. Meat Sci. 2017, 124, 77-83. [CrossRef]

49. Cavaliere, C.; Foglia, P.; Gubbiotti, R.; Sacchetti, P.; Samperi, R.; Lagana, A. Rapid-resolution liquid chromatography/mass spectrometry for determination and quantitation of polyphenols in grape berries. Rapid Commun. Mass Spectrom. 2008, 22, 3089-3099. [CrossRef] 
50. Rockenbach, I.I.; Rodrigues, E.; Gonzaga, L.V.; Caliari, V.; Genovese, M.I.; de Souza Schmidt Gonçalvesc, A.E.; Fett, R. Phenolic compounds content and antioxidant activity in pomace from selected red grapes (Vitis vinifera L. and Vitis labrusca L.) widely produced in Brazil. Food Chem. 2011, 127, 174-179. [CrossRef]

51. Moñino, I.; Martínez, C.; Sotomayor, J.A.; Lafuente, A.; Jordán, M.J. Polyphenols transmission to Segureño lamb meat from ewes' diet supplemented with the distillate from rosemary (Rosmarinus officinalis) leaves. J. Agric. Food Chem. 2008, 56, $3363-3367$. [CrossRef]

52. Gessner, D.K.; Ringseis, R.; Eder, K. Potential of plant polyphenols to combat oxidative stress and inflammatory processes in farm animals. J. Anim. Physiol. Anim. Nutr. 2017, 101, 605-628. [CrossRef]

53. McSweeney, C.S.; Palmer, B.; McNeill, D.M.; Krause, D.O. Microbial interactions with tannins: Nutritional consequences for ruminants. Anim. Feed Sci. Technol. 2001, 91, 83-93. [CrossRef]

54. Bodas, R.; Prieto, N.; García-González, R.; Andrés, S.; Giráldez, F.J.; López, S. Manipulation of rumen fermentation and methane production with plant secondary metabolites. Anim. Feed Sci. Technol. 2012, 176, 78-93. [CrossRef]

55. Mancini, S.; Secci, G.; Preziuso, G.; Parisi, G.; Paci, G. Ginger (Zingiber officinale Roscoe) powder as dietary supplementation in rabbit: Life performances, carcass characteristics and meat quality. Ital. J. Anim. Sci. 2018, 17, 867-872. [CrossRef]

56. North, M.K.; Dalle Zotte, A.; Hoffman, L.C. The effects of dietary quercetin supplementation on the meat quality and volatile profile of rabbit meat during chilled storage. Meat Sci. 2019, 158. [CrossRef] [PubMed]

57. Menchetti, L.; Brecchia, G.; Branciari, R.; Barbato, O.; Fioretti, B.; Codini, M.; Bellezza, E.; Trabalza-Marinucci, M.; Miraglia, D. The effect of Goji berries (Lycium barbarum) dietary supplementation on rabbit meat quality. Meat Sci. 2020, 161, 108018. [CrossRef]

58. Koné, A.P.; Cinq-Mars, D.; Desjardins, Y.; Guay, F.; Gosselin, A.; Saucier, L. Effects of plant extracts and essential oils as feed supplements on quality and microbial traits of rabbit meat. World Rabbit Sci. 2016, 24, 107-119. [CrossRef]

59. Króliczewska, B.; Miśta, D.; Korzeniowska, M.; Pecka-Kiełb, E.; Zachwieja, A. Comparative evaluation of the quality and fatty acid profile of meat from brown hares and domestic rabbits offered the same diet. Meat Sci. 2018, 145, 292-299. [CrossRef]

60. Hulot, F.; Ouhayoun, J. Muscular pH and related traits in rabbits: A review. World Rabbit Sci. 1999, 7, 15-36. [CrossRef]

61. Tărnăuceanu, G.F.; Pop, C.; Boişteanu, P.C. Evaluating the quality of the rabbit meat (Flemish Giant breed) during storage by refrigeration following the evolution of the pH. J. Anim. Sci. Biotechnol. 2019, 52, 134-142.

62. Sáyago-Ayerdi, S.G.; Brenes, A.; Viveros, A.; Goñi, I. Antioxidative effect of dietary grape pomace concentrate on lipid oxidation of chilled and long-term frozen stored chicken patties. Meat Sci. 2009, 83, 528-533. [CrossRef] [PubMed]

63. Bekhit, A.E.-D.A.; Holman, B.W.B.; Giteru, S.G.; Hopkins, D.L. Total volatile basic nitrogen (TVB-N) and its role in meat spoilage: A review. Trends Food Sci. Technol. 2021, 109, 280-302. [CrossRef]

64. Brenes, A.; Viveros, A.; Chamorro, S.; Arija, I. Use of polyphenol-rich grape by-products in monogastric nutrition. A review. Anim. Feed Sci. Technol. 2016, 211, 1-17. [CrossRef]

65. Yehia, H.M.; Elkhadragy, M.F.; Al-Masoud, A.H.; Al-Megrin, W.A. Citrox improves the quality and shelf life of chicken fillets packed under vacuum and protects against some foodborne pathogens. Animals 2019, 9, 1062. [CrossRef] [PubMed]

66. Ghollasi-Mood, F.; Mohsenzadeh, M.; Housaindokht, M.R.; Varidi, M. Microbial and chemical spoilage of chicken meat during storage at isothermal and fluctuation temperature under aerobic conditions. Iran. J. Vet. Sci. Technol. 2017, 8, 38-46. [CrossRef]

67. Castrica, M.; Menchetti, L.; Balzaretti, C.M.; Branciari, R.; Ranucci, D.; Cotozzolo, E.; Vigo, D.; Curone, G.; Brecchia, G.; Miraglia, D. Impact of dietary supplementation with Goji berries (Lycium barbarum) on microbiological quality, physico-chemical, and sensory characteristics of rabbit meat. Foods 2020, 9, 1480. [CrossRef]

68. Lan, Y.; Shang, Y.; Song, Y.; Dong, Q. Changes in the quality of super-chilled rabbit meat stored at different temperatures. Meat Sci. 2016, 117, 173-181. [CrossRef] [PubMed]

69. Dalle Zotte, A. Perception of rabbit meat quality and major factors influencing the rabbit carcass and meat quality. Livest. Prod. Sci. 2002, 75, 11-32. [CrossRef] 